\begin{tabular}{|l|l|}
\hline $\begin{array}{l}\text { 2. To: (Receiving Organization) } \\
\text { DISTRIBUTION }\end{array}$ & $\begin{array}{l}\text { 3. From: (Originating Organization) } \\
\text { SPECIAL ANALYTICAL SUPPORT } \\
8 C 530\end{array}$ \\
\hline $\begin{array}{l}\text { 5. Proj./Prog./Dept./Div.: } \\
\text { VAPOR/AS/SPECIAL/ANAL YTICAL/ } \\
\text { SUPPORT }\end{array}$ & $\begin{array}{l}\text { 6. Design Authority/ Design Agent/Cog. } \\
\text { Engr.: } \\
\text { RICKY MAHON 3-7437 }\end{array}$ \\
\hline
\end{tabular}

8. Originator Remarks:

SST-241-TY-102. SAMPLING USING THE VAPOR SAMPLING SYSTEM

11. Receiver Remarks: 11A. Design Baseline Document? [] Yes [X] No
4. Related EDT No.:

$N / A$

7. Purchase Order No.:

$N / A$

9. Equip./Component No.:

$\mathrm{N} / \mathrm{A}$

10. System/Bldg./Facility: $622 \mathrm{G}$

12. Major Assm. Dwg. No.: $N / A$

13. Permit/Permit Application No.: $N / A$

-14:-Required"Response bate:

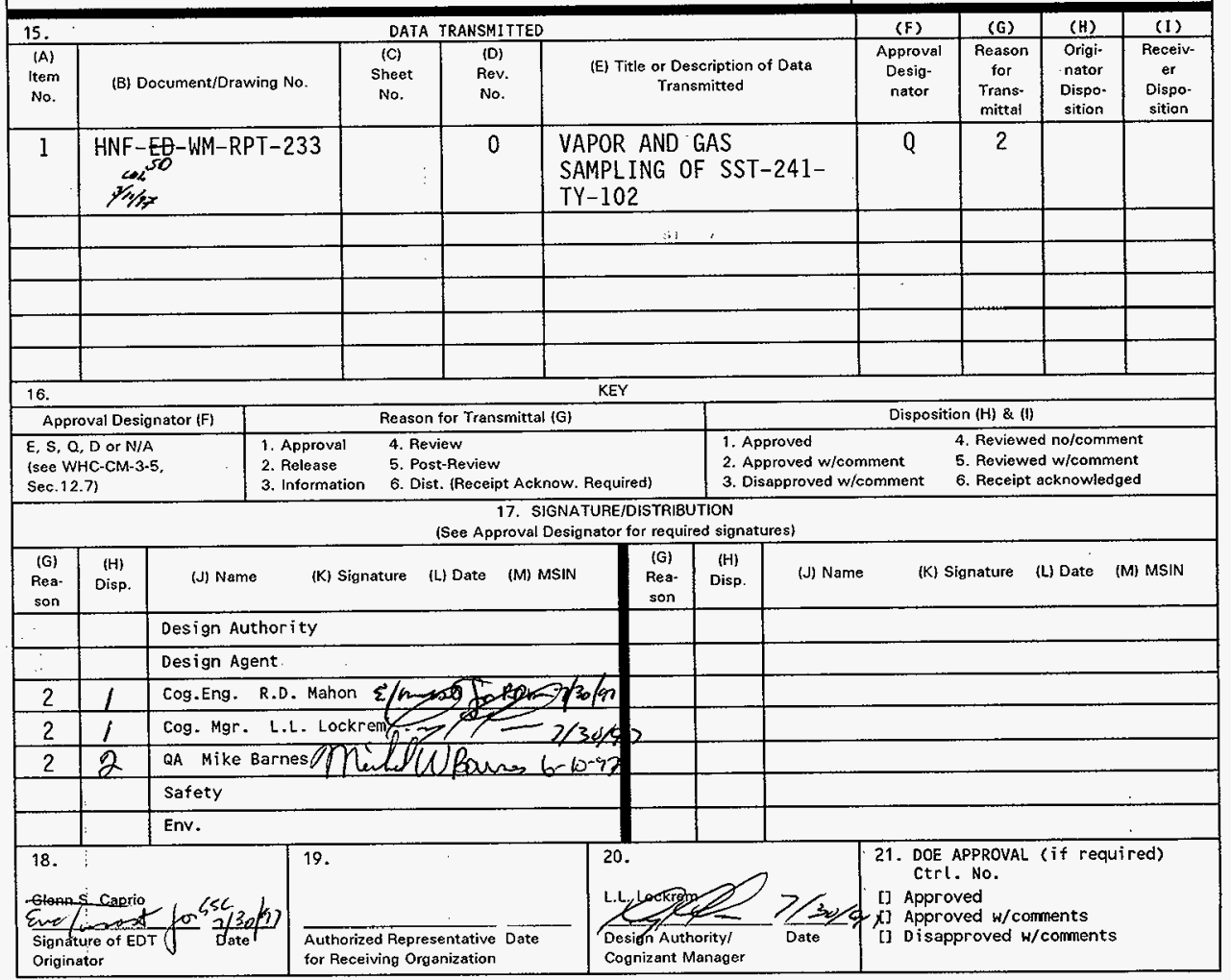




\title{
VAPOR AND GAS SAMPLING OF SINGLE-SHELL TANK 241-TY-102 USING the in Situ Vapor Sampling System
}

\author{
G.S. Caprio \\ SGN Eurisys Services Company, Richland, WA 99352 \\ U.S. Department of Energy Contract DE-AC06-96RL13200 \\ EDT/ECN: 614235 UC: 2070 \\ Org Code: 8C530 Charge Code: E62000

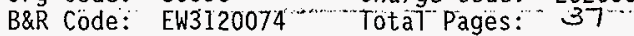 \\ Key Words: 241-TY-102, VSS, SUMMA ${ }^{\text {MM }}$, TST, SORBENT, TANK \\ Abstract: THIS DOCUMENT PRESENTS SAMPLING DATA RESULTING FROM THE APRIL \\ 12, 1996 SAMPLING OF SST 241-TY-102
}

\footnotetext{
TRADEMARK DISCLAIMER. Reference herein to any specific commercial product, process, or service by trade name, trademark, manufacturer, or otherwise, does not necessarily constitute or imply its endorsement, recommendation, or favoring by the United States Government or any agency thereof or
} its contractors or subcontractors.

Printed in the United States of America. To obtain copies of this document, contact: Document Control Services, P.O. Box 950, Mailstop H6-08, Richland WA 99352, Phone (509) 372-2420; Fax (509) 376-4989.
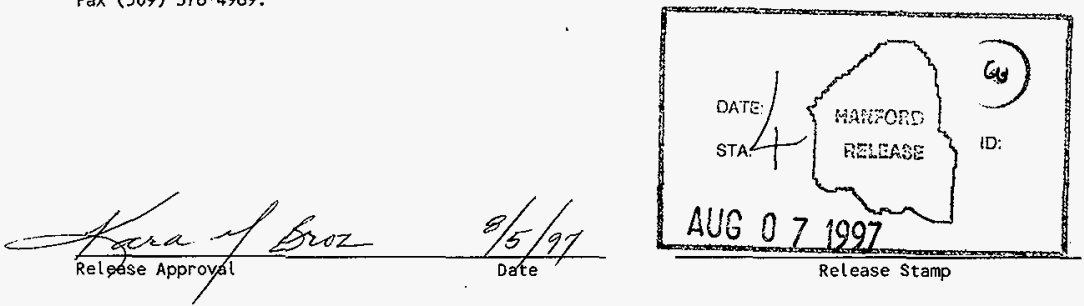
HNF-SD-WM-RPT-233, Rev. 0

\section{APPROVALS}

Document title:

Vapor and Gas Sampling of Single-Shell Tank 241-TY-102 Using the Vapor Sampling System

Approved by:

G. S. Caprio, Field Scientist

Date

Vapor Sampling Project

Special Analytical Studies

Approved by:

R. D. Mahon, Project Lead

$\overline{\text { Date }}$

Vapor Sampling Project

Special Analytical Studies

Approved by:
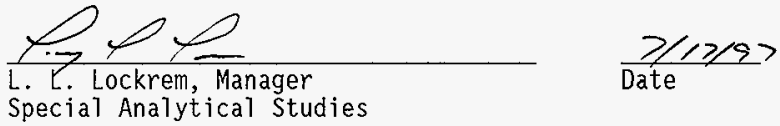


\section{CONTENTS}

$1.0 \mathrm{SCOPE} \ldots \ldots \ldots \ldots \ldots$

2.0 SAMPLING EQUIPMENT DESCRIPTION . . . . . . .......... 1

2.1 VAPOR SAMPLING SYSTEM ................ 1

3.0 SAMPLING EVENT DESCRIPTION .................. 3

3.1 SPECIFICATIONS $\ldots \ldots$

3.2 OPERATIONS AND SAMPLING PERSONNEL ........... 3

3.3 INDUSTRIAL HYGIENE FIELD RESULTS .............. 3

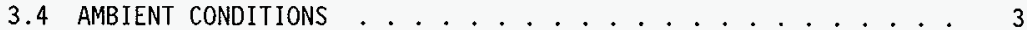

3.5 SAMPLE COLLECTION ................. . . . 3

3.6 FIELD GC/FID RESULTS . . . . . . . . . . . . . . . . 4

3.7 RADIATION SCREENING $\cdots, \cdots, \cdots, \cdots, \cdots, \cdots, \cdots$

4.0 SAMPLE CHAIN OF CUSTODY: RECEIPT, STORAGE, AND SHIPMENT . . . . 5

5.0 QUALITY ASSURANCE AND CONTROLS . . . . . . ....... 6

5.1 VAPOR SAMPLING SYSTEM CLEANING ............ 6

5.2 INSTRUMENT CALIBRATION . . . . . . . . . . . . . . . . . . 7

5.3 BLANK SAMPLES . . . . . . . . . . . . . . . 8

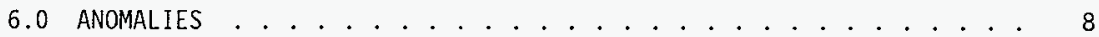

7.0 REFERENCES ..................... 8

\section{APPENDICES}

SAMPLE LOG SHEETS ....................... . . A-1

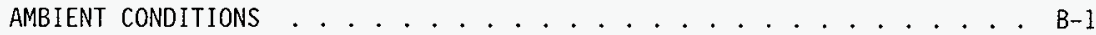

CHAIN-OF-CUSTODY FORMS .................. 
HINF-SD-WM-RPT-233， Rev. 0

LIST OF TABLES

1. Flow Control Calibration . . . . . . . . . . . . . . . . . 3

2. TOC Results . . . . . . . . . . . . . . . . . . . . . . 6

3. Radionuclide Analysis Results . . . . . . . . . . . . . . . . . . . 7

4. Pacific Northwest National Laboratory Samples . . . . . . . . . . . . 8

5. Calibration Data . . . . . . . . . . . . . . . . . . 10 
HNF-SD-WM-RPT-233, Rev. 0

\section{LIST OF TERMS}

CGI

$\mathrm{COC}$

DOT

GC/FID

GEA

$\mathrm{NH}_{3}$

$\mathrm{NO}_{2}$

$\mathrm{NO}^{2}$

$\mathrm{H}_{2} \mathrm{O}$

$O P C$

OVM

PNNL

SAS -

SML

SST

TCP

team

TOC

TST

VSS

WHC
Combustible Gas Indicator

Chain of Custody

U.S. Department of Transportation

Gas Chromatograph/Flame Ionization Detector

Gamma Energy Analysis

Ammonia

Nitrogen Dioxide

Nitric Oxide

Water Vapor

Offsite Property Control

Organic Vapor Meter

Pacific Northwest National Laboratory

Special Analytical Studies

Sampling and Mobile Laboratories

Single-Shell Tank

Tank Characterization Plan

vapor Team

Total Organic Carbon

Triple Sorbent Trap

Vapor Sampling System

Westinghouse Hanford Company 
HNF-SD-WM-RPT-233, Rev. 0

This page intentionally left blank. 
HNF-SD-WM-RPT-233, Rev. 0

\section{VAPOR AND GAS SAMPLING OF SINGLE-SHELL TANK 241-TY-102 USING THE VAPOR SAMPLING SYSTEM}

\subsection{SCOPE}

The Vapor Issue Resolution Program tasked the Vapor Team (the team) to collect representative headspace samples from Hanford Site single-shell tank (SST) 241-TY-102. This document presents sampling data resulting from the Apri1 12 , 1996 sampling of SST 241-TY-102. Analytical results will be presented in separate reports issued by the laboratories that supplied and analyzed the sampling media.

\subsection{SAMPLING EQUIPMENT DESCRIPTION}

\subsection{VAPOR SAMPLING SYSTEM}

The team, consisting of Sampling and Mobile Laboratories (SML) and Special Analytical Studies (SAS) personnel, used the vapor sampling system (VSS) to collect representative samples of the air, gases, and vapors from the headspace of SST 241-TY-102 with sorbent traps and SUMMA canisters on April 12, 1996. Mahon et a1. (1994) describes in detail the VSS, its performance, and its operation.

The VSS comprises a mobile laboratory connected to the vapor head space of the waste tank by stainless steel transfer tubing. A vacuum pump draws sample vapor from the tank headspace through the transfer tubing into the sampling manifold. Electrically activated, pneumatically actuated, valves direct sample flow within the VSS. Instrumentation housed in the mobile laboratory monitors and controls system temperature, monitors absolute and differential system pressure, meters and controls vapor mass flow, and monjtors total organic carbon (TOC) content of sample vapor using a gas chromatograph/flame ionization detector (GC/FID).

A key feature of the VSS is its use of heated transfer tubing and a heated sampling manifold. Maintaining the system at an elevated and controlled temperature prevents vapor condensation and reduces vapor adsorption on surfaces exposed to sample vapor. Mahon et al. (1994) describes various tests and observations that indicate the VSS sample transfer efficiency is consistently high.

Highly accurate mass flow controllers control the sample vapor flow rate through the sorbent traps at the sorbent trap station. The controllers FICV-1 through FICV -9 are mounted on top of the sorbent station between the inlet and

${ }^{1}$ SUMMA is a registered trademark of Molectrics, Inc., Cleveland, Ohio. 
outlet vaives of theis respective sampling ports. Controllers FICV-10 and FICV-11 are located downstream of the sorbent trap station and the in-line driers, which remove moisture from the sample vapor before it is metered. Errors associated with the mass flow controllers were determined by the Westinghouse Hanford Company (WHC) Standards Laboratory before the SST 241-TY-102 sampling event (see Table 1).

The VSS is equipped with a Hewlett Packard 5890 Series II gas chromatograph (GC) which is equipped with a flame-ionization detector (FID), $1 \mathrm{~mL}$ sample loop, 10 port injection valve, 2 meter chromatographic column, programmable oven, and a portable computer loaded with the HP-Chemstation ${ }^{2}$ software providing computer control. The oven is programmed to heat from $50^{\circ} \mathrm{C}$ to $270^{\circ} \mathrm{C}$ at a rate of $70^{\circ} \mathrm{C}$ per minute. Helium is the carrier gas, air and hydrogen the combustion gases, and nitrogen the make-up gas. The GC is plumbed to accept sample from the VSS manifold to the sample loop. After the sample is transferred. into the sample...loop... and reaches equilibrium, the run is initi.ted.. by the operator from the computer. HP-Chemstation software activates the 10 port valve which transfers a sample from the sample loop to the HP-5 column. The column is $2 \mathrm{~m}$ longand has an inside diameter of $0.25 \mathrm{~mm}$ which is coated with a chemically bonded phenyl methyl silicone layer to minimize sample interference. The sample passes through the column to the FID which generates a TOC signal for that sample. The data is then transmitted to the computer where it is stored for future retrieval and analysis. The GC/FID is configured to confirm sampling system cleanliness, and to quantitativeiy estimate TOC concentration in ambient air and tank vapor samples in rea? time.

${ }^{2}$ HP-CHEMSTATION is a Registered Trademark of the Hewlett Packard Company, Avondale, Pennsylvania. 
Table 1. Flow Control Calibration.

\begin{tabular}{|c|c|c|c|}
\hline $\begin{array}{c}\text { Flow-indicating } \\
\text { Control valve }\end{array}$ & $\begin{array}{c}\text { Typical ly } \\
\text { used Flow } \\
\text { (stdcm } / \text { min) }\end{array}$ & $\begin{array}{c}\text { \% Change from 647 } \\
\text { to Actual }\end{array}$ & $\begin{array}{c}\text { \% Change from } \\
\text { Datalogger to Actual }\end{array}$ \\
\hline 1 & 200 & -0.7 & -0.85 \\
\hline 2 & 200 & 0.05 & -0.10 \\
\hline 3 & 200 & -0.45 & -0.60 \\
\hline 4 & 200 & 0.05 & -0.10 \\
\hline 5 & 200 & 0.55 & 0.35 \\
\hline 6 & 200 & 0.25 & 0.05 \\
\hline 7 & 200 & 0.4 & 0.20 \\
\hline 8 & 200 & 0.25 & -1.81 \\
\hline 9 & 50 & -0.128 & -0.27 \\
\hline 10 & 200 & -1.1 & -1.20 \\
\hline 11 & 5000 & 0.332 & 0.17 \\
\hline
\end{tabular}

The system is multi-point calibrated at the weather station on an as available basis and last performed January 1995. The GC/FID has displayed a high degree of stability over a period of months. For further details, see Section 3.6, Field GC/FID Results.

Sorbent trap samples, pencil-size stainless steel or glass tubes that contain vapor-adsorbing media, are collected at the sorbent trap station of the sampling manifold. : The rate and the duration of flow, as specified by the analytical laboratory providing the sample media, determines the total volume. of vapor to be passed through the tube. Virtualiy all the target analytes are then trapped in the tube by the adsorbing media. Analyte concentration in the tank vapor can then be ascertained from the sorbent media analysis knowing the total volume of vapor which passed through the sorbent trap.

SUMMA ${ }^{\text {MH }}$ canisters, stainless steel vessels with their internal surfaces chemically passivated by the SUMMA" process to minimize adsorption of gases and vapors, are used to sample tank vapor from the SUMMA sampling station on the sampling manifold. The precleaned and evacuated SUMMA canisters are filled with sample vapor by opening a manually operated valve, which is then shut after pressure equilibration to seal the sample inside. SUMMA canisters allow a 6 liter sample to be transported to an analytical laboratory. 


\subsection{SAMPLING EVENT DESCRIPTION}

\subsection{SPECIFICATIONS}

The Vapor Issue Resolution Program specifies sampling requirements in WHC-SD-WM-TP-335 Rev 2, Vapor Sampling and Analysis Plan (Homi 1996), which a] so specifies the types and number of samples to be collected, flow rates, and durations. These key sampling parameters are summarized on the sample log sheets in Appendix A. In addition to the sample log sheets, checksheets for each individual sample help ensure correct sampling procedures. The team retains these documents in this sample event's project-specific file, S6-037.

\subsection{OPERATIONS AND SAMPLING PERSONNEL}

Steve Carter was the Tank Farm Operations person-in-charge. The team members included:

G. S. Caprio, Field Scientist

R. D. Mahon, Vapor Sampling Lead.

The VSS waS set up at SST 241-TY-102 on April 11, 1996 and was allowed to warm up overnight. Sampling began shortiy after 9:30 a.m. on April 12, 1996, and was completed by $11: 30 \mathrm{a} . \mathrm{m}$. the same day.

\subsection{INDUSTRIAL HYGIENE FIELD RESULTS}

Prior to hooking up to SST 241-TY-102, an industrial hygiene technician field tested tank vapors. The technician purged the instrument/vent header for 5 minutes and then field measured vapor stream contents using a combustible gas indicator (CGI) and an organic vapor meter (OVM). The measurements were verbally reported, $L E L 0 \%, \mathrm{NH}_{3}<2 \mathrm{ppm}, 0_{2} 20.7 \%$, and TOC was not recorded.

\subsection{AMBIENT CONDITIONS}

The weather the day of the sampling event, April 12, 1996 was cool and overcast with winds from the northwest at about 20 miles per hour. Graphs of ambient temperatures and pressures taken at the Hanford Meteorological Station, which is about 2 miles east of TY-Farm, are provided in Appendix B.

\subsection{SAMPLE COLLECTION}

The hot-water-jacketed sampling probe was located in Riser 5 of SST 241-TY-102. The probe length, from the sample inlet to the top of the riser flange, was 6.1 meters. 
Al1 zones of the VSS were heated to $60{ }^{\circ} \mathrm{C}$ during setup at SST 241-TY-102 on April 11, 1996. The team stabilized the VSS temperature zones by 9:30 a.m. on April 12, 1996, and the system was ready to collect samples. Measured according to the VSS operating procedure, the pressure and temperature of SST 241-TY-102 were 988 mbar (741.3 torr) and $13.7{ }^{\circ} \mathrm{C}$, respectively. The sample log sheets (Appendix A) provide a complete chronology of the sample event including start and end times, flow rates, volumes, and specific sample identifiers.

Approximately 23 hours before the first samples were collected, the team began heating the VSS transfer tubing and sampling manifold. During this warmup period, the team began a purge of all vapor transfer tubing and the sampling manifold with ambient air. Prior to sampling tank vapors on April 12, 1996, the team collected two SUMMA ${ }^{\text {th }}$ canister samples of ambient air, one manually 10 meters upwind of the VSS connection with SST 241-TY-102, and the other using the VSS sampling manifold: The former was collected to estabtish background levels of trace organic vapors, and the latter was collected to establish the cleanliness of the sampling manifold.

A leak check of the VSS sampling manifold and transfer tubing was performed. The system was evacuated to 289 mbar (216.9 torr) and leakage of ambient air into the system was observed by monitoring system pressure for 15 minutes. Leakage resulted in an increase of 4.8 mbar (3.6 torr) in system pressure during the 15 minute test. Given a system volume of not more than $10 \mathrm{~L}$, this pressure increase corresponds to a leak rate of approximately $11.1 \mathrm{ml} / \mathrm{min}$. This leak rate was then estimated for average SUMMA ${ }^{\text {TH }}$, Triple Sorbent Trap (TST), and sorbent sampling pressures. It was found that for the SUMMA canisters, dilution by ambient air was approximately $0.1 \%$, for TST traps sampled at $100 \mathrm{~mL} / \mathrm{min}$ was $0.9 \%$, and for sorbent traps the dilution was approximately $0.4 \%$.

The sampling valve was opened and the VSS was purged with sample vapor from SST 241-TY-102 for 30 minutes at a total flow rate of $5.46 \mathrm{~L} / \mathrm{min}$. This purge was performed to flush ambient air from the system and saturate the system's active adsorption sites. Because the volume of transfer tubing and the sampling manifold upstream of the sampling devices is estimated to be no more than $10 \mathrm{~L}$, this purge provided about 16.4 air turnovers in the system.

One analytical laboratory provided sample media. Pacific Northwest National Laboratory (PNNL) provided SUMMA ${ }^{T h}$ canisters, sorbent traps for organic vapors, ammonia $\left(\mathrm{NH}_{3}\right), \mathrm{NO}_{x}$, and water vapor $\left(\mathrm{H}_{2} \mathrm{O}\right)$, and TST sorbent traps.

\subsection{FIELD GC/FID RESULTS}

The GC was single point calibrated on the day of sampling using $6.0 \mathrm{ppmC}$ Propane standard by Scott Specialty Gas. The standard is an E.P.A. Protocol Gas that is $\pm 2 \%$ NIST traceable.

Table 2 displays the Field GC/FID results from the sampling of $241-$ TY-102. 
Table 2. TOC Results.

\begin{tabular}{|c|c|c|c|}
\hline $\begin{array}{c}\text { Number of } \\
\text { Runs }\end{array}$ & Description & $\begin{array}{c}\text { Average TOC } \\
\text { Concentration } \\
\text { (ppmC) }\end{array}$ & $\begin{array}{c}\text { \% Standard } \\
\text { Deviation }\end{array}$ \\
\hline 3 & Propane & 6.00 & 0.86 \\
\hline 4 & Ambient & 3.46 & 1.07 \\
\hline 3 & Tank Vapor & 3.51 & 0.79 \\
\hline
\end{tabular}

\subsection{RADIATION SCREENING}

Samples are unconditiona $77 y-r e$ leased from the-SSF farm-in-accordance-with 1995-33300-RSP-03, Release of Vapor Sampling Equipment (WHC 1995c).

Radiological screening results are used to determine (1) if the samples must be shipped as radioactive or nonradioactive in accordance with U.S. Department of Transportation (DOT) regulations and (2) if the samples meet the laboratory acceptance criteria.

The DOT limits for shipping a nonradioactive sample are $2000 \mathrm{combined} \mathrm{pCi} / \mathrm{g}$ of beta-gamma activity and alpha activity. Samples exceeding these DOT limits may be shipped as radioactive material if the samples do not exceed the following laboratory acceptance criterja:

PNNL: Beta-gamma activity $<400 \mathrm{pCi} / \mathrm{g}$ of sampie media. Alpha activity $<100 \mathrm{pCi} / \mathrm{g}$ of sample media.

To protect the sampling manifold and sampling devices from radioactive particulates, all sample vapor for the April 12, 1996, SST 241-TY-102 vapor sampling event was drawn through a serjes of four filters placed upstream of the sampling manifold. These four filters were in place any time tank vapors were flowing through the system. When sampling was complete, the filters were removed and assigned unique sample identifiers. All four filters were submitted to Laboratory 222-S for total alpha, total beta, and gamma energy analysis (GEA). The filter closest to the sampling manifold was analyzed to determine if the samples met DOT shipping criteria and laboratory acceptance criteria. Moisture from the tank vapors was collected in a silica gel trap through one of the sorbent station ports and analyzed for tritiated water. SST 241-TY-102 filter and silica gel analysis results are shown in Table 3 . The vapor team scientists use the activity results in Table 3 to calculate $\mathrm{pCi} / \mathrm{g}$ of sample media. The team maintains this information in the project-specific file. The results in Table 3 indicate that the samples collected from SST 241-TY-102 met the laboratory acceptance criteria and the DOT definition of a nonradioactive shipment. 
Table 3. Radionuclide Anatysis Results.

\begin{tabular}{|c|c|c|c|}
\hline Filter & $\begin{array}{c}\text { Sample } \\
\text { Identifier }\end{array}$ & $\begin{array}{l}\text { Activity Results } \\
\text { (pCi/sample) }\end{array}$ & $\begin{array}{l}\text { Activity } \\
\text { (pCi/L of tank gas) }\end{array}$ \\
\hline $\begin{array}{l}\text { Upstream filter } \\
\text { (box) }\end{array}$ & S6037-A21.0U1 & $\begin{array}{l}\text { Total Alpha }=548 \\
\text { Total Beta }=699 \\
\text { GEA }=\text { <detectable }\end{array}$ & $\begin{aligned} &=1.99 \\
&=2.54 \\
&=\text { <detectable }\end{aligned}$ \\
\hline $\begin{array}{l}\text { Downstream } \\
\text { filter (box) }\end{array}$ & S6037-A22.0D1 & $\begin{array}{c}\text { Total Alpha }=<0.485 \\
\text { Total Beta }=2.6 \\
\text { GEA }=\text { <detectable }\end{array}$ & $\begin{array}{c}=<\text { detectable } \\
=0.01 \\
=<\text { detectable }\end{array}$ \\
\hline $\begin{array}{l}\text { Upstream filter } \\
\text { (VSS) }\end{array}$ & S6037-A23.0U2 & $\begin{array}{c}\text { Total Alpha }=<0.485 \\
\text { Total Beta }=6.13 \\
\text { GEA }=\text { <detectable }\end{array}$ & $\begin{array}{c}=<\text { detectable } \\
=0.02 \\
=<\text { detectable }\end{array}$ \\
\hline $\begin{array}{l}\text { Downstream } \\
\text { filter (VSS) }\end{array}$ & $\$ 6037-A 24.002$ & $\begin{array}{c}\text { Total Alpha }=<0.485 \\
\text { Total Beta }=<1.99 \\
\text { GEA }=<\text { detectable }\end{array}$ & $\begin{array}{l}=<\text { detectable } \\
=<\text { detectable } \\
=<\text { detectable }\end{array}$ \\
\hline Tritium trap & S6037-A03.0T1 & Tótal activity $=<9.33$ & $=<9.33^{c}$ \\
\hline
\end{tabular}

NOTES:

The samples are nonradioactive. These results were evaluated against 7 aboratory acceptance criteria and DOT limits.

${ }^{a}$ All less than $(<)$ values represent the minimum detection limits at Laboratory $222-S$.

Numbers based on an approximation of the total volume of tank vapor through the filters. Appendix $A$ and the sample checksheets were used to estimate a total flow through the VSS of $275.2 \mathrm{~L}$.

cNumber is calculated using a total volume of $1 \mathrm{~L}$ passing through the tritium trap.

\subsection{SAMPLE CHAIN OF CUSTODY: RECEIPT, STORAGE, AND SHIPMENT}

A1] sorbent trains, TSTs, and SUMMA ${ }^{\top *}$ canisters received from PNNL are kept in a custody locked storage area maintained by SML. Sorbent trains, tubes and traps were maintained at $4 \pm 2{ }^{\circ} \mathrm{C}$ in a refrigeration unit: SUMMA ${ }^{\mathrm{HH}}$ canisters were stored in the same locked storage area, but were not, refrigerated. The sample media was picked up from PNNL by SML and transported in a government vehicle to a custody locked storage area.

After sampling, the PNNL sorbent tubes, TSTs, and SUMMA ${ }^{\text {DN }}$ canisters were transported by government vehicle directly to PNNL and delivered to J. A. Edwards on April 17, 1996. 
Table 4 Tists the sample identifiers, sample types, and COC form numbers for all PNNL samples.

Table 4. Pacific Northwest National Laboratory Samples.

\begin{tabular}{|c|c|c|}
\hline Sample Identifier & Sample Type & COC Number \\
\hline S6037-A01.236 & Ambient upwind SUMMA ${ }^{\text {nt }}$ & 100066 \\
\hline $\mathrm{S} 6037-\mathrm{A} 02.239$ & "Ambient" SUMMA" (VSS) & 100066 \\
\hline$S 6037-A 04.240$ & SUMMA & 100066 \\
\hline S6037-A05.249 & SUMMA ${ }^{\mathrm{M}}$ & 100066 \\
\hline$S 6037-A 06.251$ & SUMMA ${ }^{\mathrm{nk}}$ & 100066 \\
\hline S6037-A07.S49 & $\mathrm{NH}_{3} / \mathrm{NO}_{x} / \mathrm{H}_{2} \mathrm{O}$ sorbent & 100068 \\
\hline S6037-A08.S50 & $\mathrm{NH}_{3} / \mathrm{NO}_{x} / \mathrm{H}_{2} \mathrm{O}$ sorbent & 100068 \\
\hline S6037-A09.S51 & $\mathrm{NH}_{3} / \mathrm{NO}_{\mathrm{x}} / \mathrm{H}_{2} \mathrm{O}$ sorbent & 100068 \\
\hline S6037-A10.S52 & $\mathrm{NH}_{3} / \mathrm{NO}_{\mathrm{x}} / \mathrm{H}_{2} \mathrm{O}$ sorbent & 100068 \\
\hline S6037-A15.S53 & $\mathrm{NH}_{3} / \mathrm{NO}_{x} / \mathrm{H}_{2} \mathrm{O}$ field blank & 100068 \\
\hline S6037-A16.S54 & $\mathrm{NH}_{3} / \mathrm{NO}_{x} / \mathrm{H}_{2} \mathrm{O}$ field blank & 100068 \\
\hline S6037-A11.921 & TST & 100067 \\
\hline S6037-A12.922 & TST & 100067 \\
\hline S6037-A13.923 & TST & 100067 \\
\hline$\$ 6037-A 14.925$ & TST & 100067 \\
\hline S6037-A17.926 & TST Field Blank & 100067 \\
\hline S6037-A18.927 & TST Field Blank & 100067 \\
\hline S6037-A19.928 & TST Trip Blank & 100067 \\
\hline $\mathrm{S} 6037-\mathrm{A} 20.929$ & TST Trip Blank & 100067 \\
\hline
\end{tabular}

From the time that samples are received by SML until they are shipped back to the analytical laboratory, all COCS are maintained by SML in accordance with WHC-IP-1127-1.3, Chain-of-Custody/Special Analysis Request for RCRA and CERCLA Protocol Samples (WHC 1995a). Copies of the completed COC forms for this sampling event are included in Appendix C. 


\subsection{QUALITY ASSURANCE AND CONTROLS}

\subsection{VAPOR SAMPLING SYSTEM CLEANING}

Immediately prior to sampling of SST 241-TY-102, the VSS manifold and vapor sample transfer tubing was heated to $60{ }^{\circ} \mathrm{C}$ and ambient air was purged through the system for 1367 minutes. Also, all pertinent system valves were actuated to release any contaminants that may have collected in the VSS vaTves themselves. After this purge an ambient air sample was drawn through the VSS manifold and a GC/FID run was initiated. No significant level of contaminants was detected. A second ambient air GC/FID run confirmed that the VSS manifold and transfer tubing was free of organic remnant residue down to ambient levels. A SUMMA ${ }^{\text {nk }}$ canister ambient air sample was then collected to confirm by Taboratory anatysis that the VSS sampling manifold was free of trace organic contaminants (or to determine which contaminants were present and at what concentration), as discussed in Section 3.5. For further details, refer to Appendix E of WHC-IP-1127-4.10 (WHC 1995b) and the project-specific file located with the team. 


\subsection{INSTRUMENT CALIBRATION}

Instruments located in the VSS are calibrated on an annual basis at the WHC Standards Laboratory. VSS instrumentation calibration data, maintained in files by the team, are summarized in Table 5. According to the calibration schedule shown in Tab?e 5, all instrumentation was within its calibration period during the SST 241-TY-102 sampling event.

Due to calibration discrepancies, the mass flow measurements for this sampling event may have an error of $6 \%$ to $14 \%$. A detailed description of this discrepancy can be found in internal memo 75820-96-028.

Table 5. Calibration Data.

\begin{tabular}{|c|c|c|c|}
\hline Element & Calibration Date & Expiration Date & $\begin{array}{c}\text { WHC Standards } \\
\text { Laboratory Code }\end{array}$ \\
\hline FICV-1 & $5 / 08 / 95$ & $5 / 08 / 96$ & $518-28-03-012$ \\
\hline FICV-2 & $5 / 08 / 95$ & $5 / 08 / 96$ & $518-28-03-008$ \\
\hline FICV-3 & $5 / 08 / 95$ & $5 / 08 / 96$ & $518-28-03-004$ \\
\hline FICV-4 & $5 / 08 / 95$ & $5 / 08 / 96$ & $518-28-03-006$ \\
\hline FICV-5 & $5 / 08 / 95$ & $5 / 08 / 96$ & $518-28-03-011$ \\
\hline FICV-6 & $5 / 08 / 95$ & $5 / 08 / 96$ & $518-28-03-009$ \\
\hline FICV-7 & $5 / 08 / 95$ & $5 / 08 / 96$ & $518-28-03-014$ \\
\hline FICV-8 & $5 / 08 / 95$ & $5 / 08 / 96$ & $518-28-03-013$ \\
\hline FICV-9 & $5 / 08 / 95$ & $5 / 08 / 96$ & $518-28-03-007$ \\
\hline FICV-10 & $5 / 08 / 95$ & $5 / 08 / 96$ & $518-28-03-010$ \\
\hline FICV-11 & $5 / 08 / 95$ & $5 / 08 / 96$ & $518-28-03-005$ \\
\hline PE-1 & $5 / 04 / 95$ & $5 / 04 / 96$ & $518-80-02-005$ \\
\hline PE-2 & $5 / 04 / 95$ & $5 / 04 / 96$ & $518-80-02-006$ \\
\hline PE-3 & $5 / 04 / 95$ & $5 / 04 / 96$ & $518-80-02-008$ \\
\hline PE-4 & $5 / 04 / 95$ & $5 / 04 / 96$ & $518-80-02-007$ \\
\hline PD-1 & $5 / 04 / 95$ & $5 / 04 / 96$ & $518-80-02-004$ \\
\hline PD-2 & $5 / 04 / 95$ & $5 / 04 / 96$ & $518-80-02-003$ \\
\hline Temperature & $08 / 25 / 95$ & $08 / 25 / 96$ & $804-67-74-009$ \\
\hline Control System & & & \\
\hline \hline & & & \\
\hline & & & \\
\hline & & & \\
\hline
\end{tabular}




\subsection{BLANK SAMPLES}

Trip blanks are samples that accompany the sample media from the point of generation through sample analysis. They are transported to the field with the sample collection media but remain unopened during the sampling event. Analysis of trip blanks is used to assess cross-contamination of sample media during field transport and storage.

Field blanks are sampling devices similar to trip blanks. They are prepared and handled in the same manner as the sampling media, but no tank vapors are drawn through them.

Spiked blanks are prepared as regular sampling media but also contain a known amount of special analyte. Tank vapors are drawn through these blanks and they are handled and analyzed just like any other sample. Analysis of the spiked blanks is used to evatuate potential samp te Toss during shipment or storage.

Ambient blanks are samples of ambient air collected at the sampling location. Analysis of ambient blanks is used to assess contamination that may be present in the atmosphere or in the transfer tubing or sampling manifold of the VSS immediately prior to sampling operations.

Table 4 1ists sample blanks used during the sampling of SST 241-TY-102.

\subsection{ANOMALIES}

Ail samples were collected in accordance with the TCP and WHC-IP-1127-4.5, Collection of SUMMA Canisters and Sorbent Tube Samples Using the Vapor Sampling System (1995b). There were no anomalies during the VSS sampling event. 


\subsection{REFERENCES}

49 CFR 100-177, 1992, "Transportation," Code of Federal Regulations, as amended.

Homi, C. S., 1996, Vapor Sampling and Analysis P7an, WHC-SD-WM-TP-335 Rev. 1D, Westinghouse Hanford Company, Richland, Washington.

Mahon, R. D., C. M. Jones, and M. S. Story, 1994 (draft), Evaluation of the Capabilities and Use of the Vapor Sampling System for Tank Headspace Sampling and Characterization, SD-WM-RPT-094, Westinghouse Hanford Company, Richland, Washington.

Trible, T. C., Viswanath, R. S., 1996c, Recommendation concerning the ISVS/VSS comparison study data with respect to calibration errors in Mass flow monitors and controllers, (internal memo 75820-96-028 to L.D. Pennington, August 28), Westinghouse Hanford Company, Richland, Washington.

WHC, 1995a, Chain-of-Custody/Special Analysis Request for RCRA and CERCLA Protoco7 Samples, Procedure WHC-IP-1127-1.3, Rev. 1, Westinghouse Hanford Company, Richland, Washington.

WHC, 1995b, Collection of SUMMA Canisters and Sorbent Tube Samples Using the Vapor Sampling System (VSS), Procedure WHC-IP-1127-4.5, Westinghouse Hanford Company, Richland, Washington.

WHC, 1995c, Release of Vapor Sampling Equipment, Procedure 1995-33300-RSP-03, Westinghouse Hanford Company, Richland, Washington. 
HNF-SD-WM-RPT-233, Rev. 0

This page intentionally left blank. 
HNF-SD-WM-RPT-233, Rev. 0

\section{APPENDIX A}

\section{SAMPLE LOG SHEETS}

A- 1 
HNF-SD-WM-RPT-233, Rev. 0

This page intentionally left blank. 
Set up VSS (Section A)(Temperature set point $=60^{\circ} \mathrm{C}$ )

Ensure HEPA filters are installed

Ensure connection to sample probe

System status check sheet. (Verify zones are to temp)

Tank Temperature $\quad 13.7 \mathrm{C}$

GC Standard Runs

GC Ambient Air Runs through port 10

$$
13.7 \mathrm{C}
$$

VSS Personnel: Glenn Caprio and Rick Mahon

Trailer Personnel: None

$$
\text { ORNL/PNL Port }
$$

Description

Sample ID Valve \#

Flow

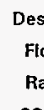

$\begin{array}{ccc}\text { Desired } & \text { Desired } & \text { Actu } \\ \text { Duration } & \text { Total } & \text { Flow } \\ \text { (min.) } & \text { Flow } & \text { Rat } \\ & \text { SccM } & \text { Scc }\end{array}$

Purge with ambient air for $30 \mathrm{~min}$.

$\operatorname{sccm}$

ScCM

SCCM

Actual

Start

Actual

Actual

Actual

Time

End

Total

Total

Time

Time

Flow

$4 / 11 / 96 \quad 4 / 12 / 96$

(min.)

Liters

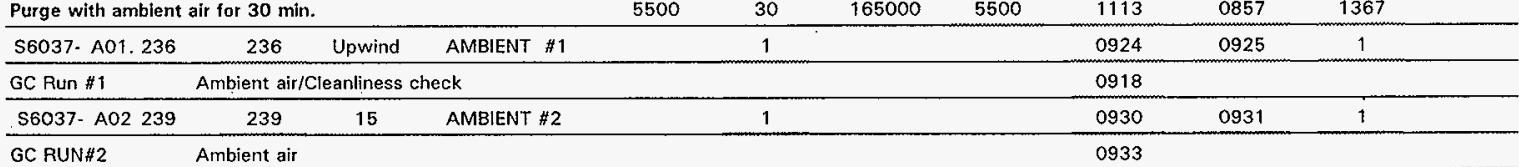

LEAK CHECK (APPENDIX A)

Leak Rate:

14.4 Torr/Hr

Purge with tank air for $30 \mathrm{~min}$

5500

$30 \quad 165000 \quad 5500$

1035

30

165.00

Measure tank pressure

$\mathrm{PE}-1=741.3$

1037

\begin{tabular}{|c|c|c|c|c|c|c|c|c|c|c|c|c|c|}
\hline S6037- & $\mathrm{AO3}$ & OT 1 & S96WV0038 & 5 & Tritium Trap & 200 & 5 & 1000 & 200.00 & 1044 & 1049 & 5 & 1.00 \\
\hline 56037 & $\mathrm{~A} 04$ & 240 & 240 & 11 & SUMMA \#3 & & 1 & & & 1054 & 1055 & 1 & 6.00 \\
\hline S6037. & A05 & 249 & 249 & 13 & SUMMA $\# 4$ & & 1 & & & 1058 & 1059 & 1 & 6.00 \\
\hline 56037. & A06 & 251 & 257 & 15 & SUMMA \#5 & & 1 & & & 1103 & 1104 & 1 & 6.00 \\
\hline GCRUN & $\# 4$ & ITank & run \#21 & & & & & & & 1106 & & & \\
\hline
\end{tabular}

GCRUN \#3 (Tank run \#1) 1039




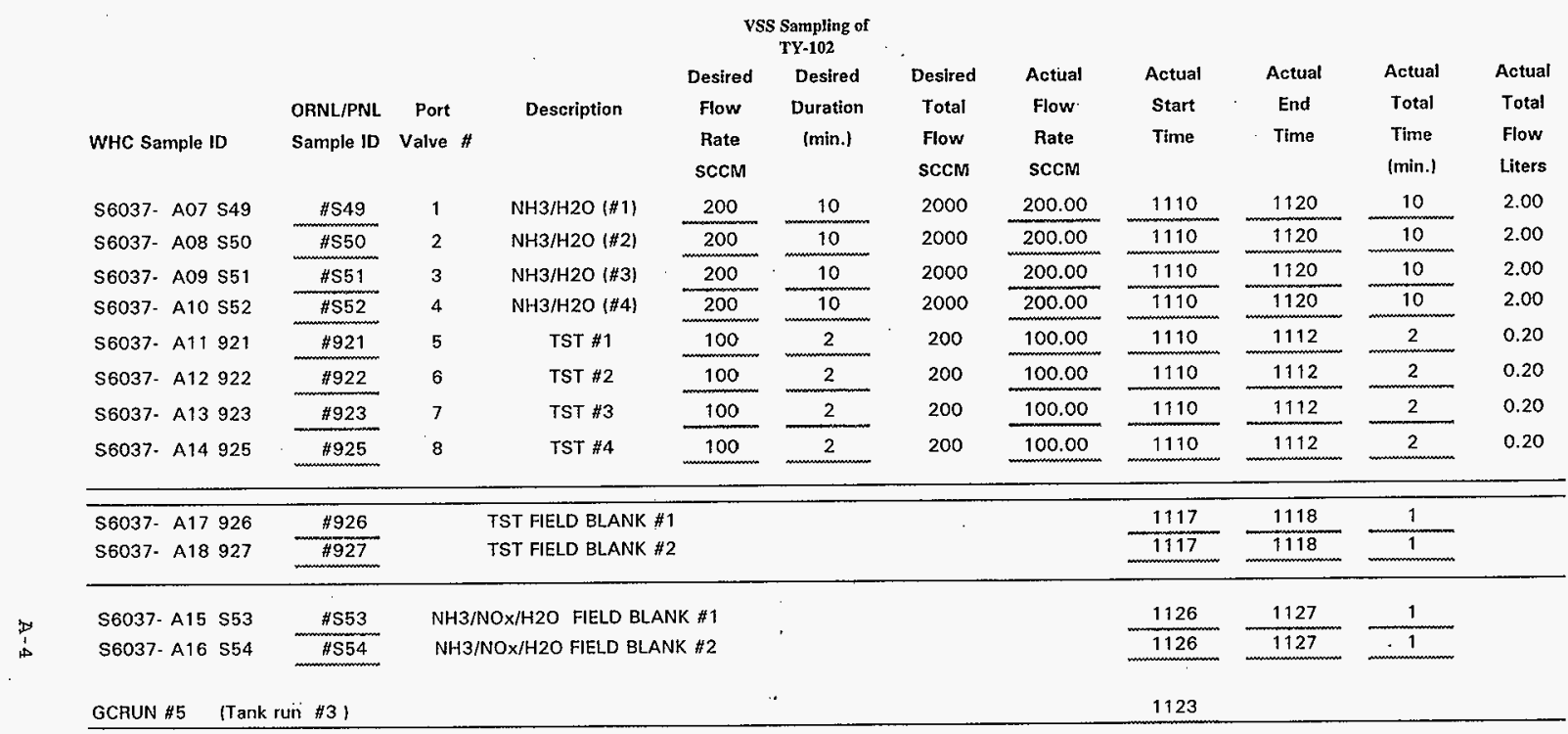




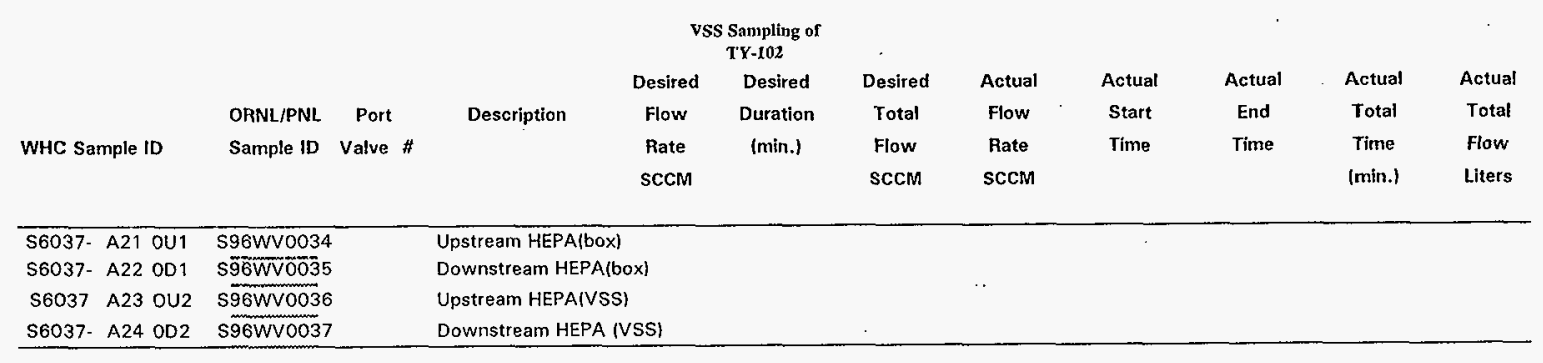

Trip Blanks (DO NOT EXPOSE)

\begin{tabular}{lll}
\hline S6037. A19 928 & TST\#928 & TST TRIP \#1 \\
S6037- A20 929 & TSTH929 & TST TRIP \#2 \\
\hline
\end{tabular}


TY-102

TOTAL TANK VAPOR USED

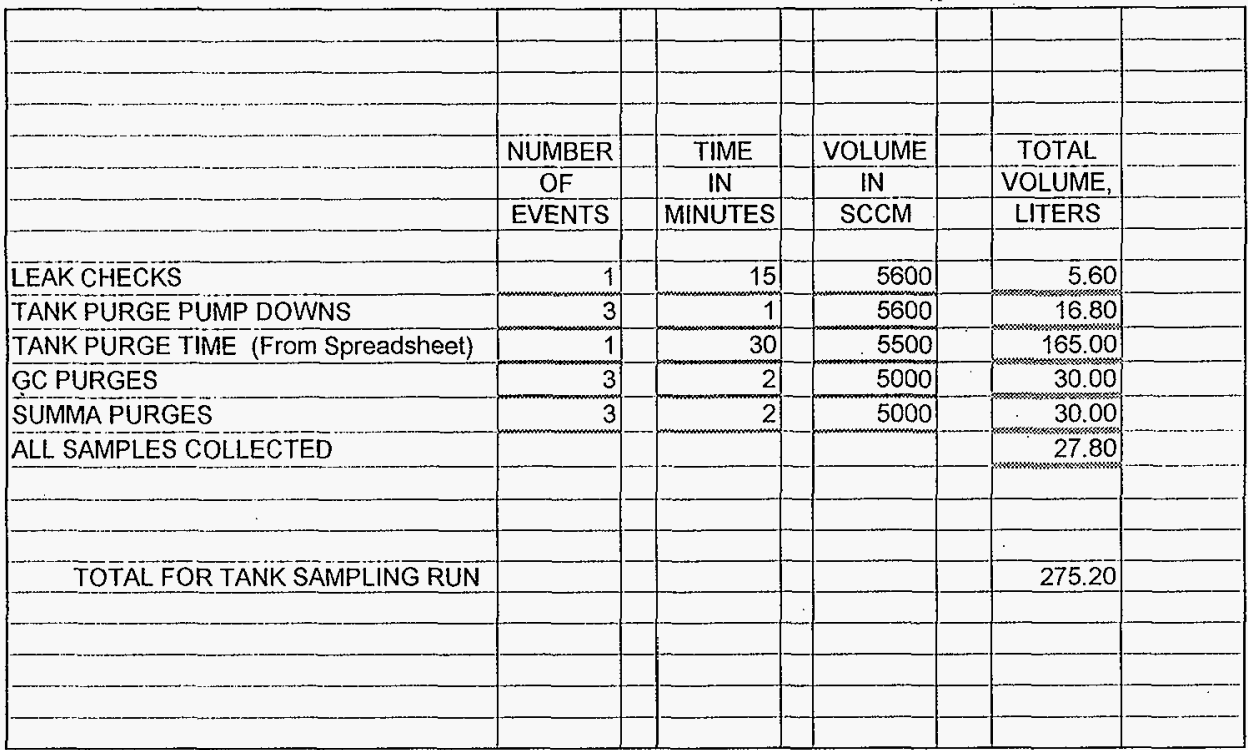




\begin{tabular}{|c|c|c|c|c|c|c|c|c|c|c|}
\hline & & & & & & & & & 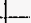 & \\
\hline & 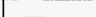 & & & & & & & & . & \\
\hline $56037 . A 21001,596 \mathrm{~W} 0034$ & & & & & & $\$ 6037 . A 22.001 / S 96 W V 0035$ & & & & \\
\hline FILTER BOX UPSTREAM FITER & Liters & pCi $/$ filter & & pci / liter & & FILTER BOX DOWNS IREAM FILTER & Liters & pci / filter & [ & pCilliter \\
\hline TOTAL YOL UUME & 275.20 & & 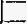 & & & TOTAL VOLUME & 275.20 & & 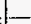 & \\
\hline ALPPHA & & $54 \overline{0} . \overline{00}$ & & 1.99 & & ALPHA & & $<0.485$ & 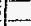 & $<$ Detectable \\
\hline BETA & & 699.00 & & 2.54 & & BETA & & $\ldots 2.6$ & $\ldots$ & 0.01 \\
\hline GEA-Co-60 & & $\leq 13.58$ & 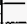 & $<$ Detectable & & GEA. CO-60 & & $\leqslant 13.54$ & - & CDetectable \\
\hline Cs-134 & & $\leq 1282$ & & $<$ Detectable & & Cs-134 & & $<8.503$ & 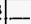 & $\leq$ Detectable \\
\hline$\left[\begin{array}{c}\mathrm{C} s-13] \\
\end{array}\right.$ & & $<19.60$ & & $\leq$ Detectable & & cs- 137 & & $<16.83$ & 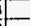 & $<$ Detectable \\
\hline EU-152 & & $<56.26$ & & CDetectable & & Eu-152 & & $\leq 56.34$ & 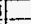 & $<$ Detectable \\
\hline Eu-154 & & $<45.42$ & & $\leq$ Delectable & & Eu-154 & & $<39.35$ & . & $<$ Detectable \\
\hline EU-155 & & $<42.31$ & & $<$ Delectable & & Eu-155 & & $\leq 33.36$ & 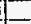 & <Detectable \\
\hline & & & & & & & & & - & \\
\hline & & & & & & & & & 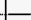 & \\
\hline & & & & & & & & & $\ldots$ & \\
\hline $56037-\mathrm{A} 23.0 \mathrm{U} 2 \mathrm{S96 \textrm {W } Y 0 0 3 6}$ & & & & & & $\$ 6037-A 24,002 / 596 W V 0037$ & & & ב & \\
\hline VSS UPSTREAM FILTER & Liters & pcijrilter & 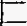 & pcillier & & VSS DOWNSTREAM FILTER & Liters & pCi / filler & 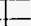 & _eGi/liter \\
\hline TOTAL VOLUME & 275.20 & & 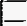 & & & TOTAL FLOW & 275.20 & & - & \\
\hline ALPHA & & $<0.485$ & Z & $\leq$ Delectable & & ALPHA & & $<0.485$ & - & $<$ Detectable \\
\hline BETA & & 6.13 & ... & 0.02 & & BETA & & $\leq 1.99$ & - & $\leq$ Detectable \\
\hline GEA. $\mathrm{CO}-60$ & & $\leq 9.744$ & 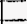 & $\angle$ Detectabie & & $\mathrm{GEA} \cdot \mathrm{C} 0-60$ & & $<$ Detectable & 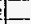 & $<$ Detectable \\
\hline Cs-134 & & $<10.35$ & & $<$ Detectable & & Cs: 134 & & c Detectable & 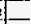 & $<$ Detectable \\
\hline Cs-137 & & $<12.40$ & te & $\leq$ Detectable & & Cs. 137 & & CDetectable & & $<$ Detectable \\
\hline$E u-152$ & & $<52.67$ & 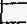 & $<$ Detectabie & & EU.152 & & $<$ Detectable & 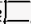 & $<$ Delectable \\
\hline${ }_{\mathrm{E}} \mathrm{-1}-154$ & & $<37.57$ & 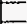 & $<$ Detectable & & Eu. 154 & & $\leq$ Detectable & 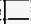 & $<$ Detectabie \\
\hline Eu-i55 & & $<2 \overline{8} . \overline{04}$ & & $<$ Detectable & & Eu. 155 & & \& Detectable & 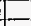 & $<$ Detectable \\
\hline & $\ldots$ & & & & & & & & - & \\
\hline S6037-A03.0Tt / 596 WVO038 & & & & & & & & & 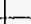 & \\
\hline TRITUUM IRAP & Liters & pci/filler & 工 & ECi/liter & & & & & $\ldots$ & \\
\hline TOTAL VOLUME & -1 & & & & & & & & $\ldots$ & \\
\hline TOTAL ACTIVITY & & $<9.33$ & & $\leq$ Detectable & & & & & $\ldots$ & \\
\hline & & & & & & & & & _. & \\
\hline SAMPLE EXPOSURE ANALAYSIS USING & V's & STREAMA FiLTE & RA & $\frac{1}{\text { NALISSIS ASP }}$ & $\cos 5 i \operatorname{lig}$ & LE EXPOSURE LEVEL & & & - & \\
\hline$=\mathrm{BEIA}$ and $\mathrm{AL} P H A$ Less than & OT shipping & limits & & & & & & & - & \\
\hline & & & & & & & & & _ & \\
\hline SORBENT SAMPLING USed $\overline{5} g$ lor sorber & mass & & 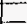 & & & ISI SAMPLING USEd $4.5 \mathrm{~g}$ for TST mass & & & ב & \\
\hline TOTAL VOLUME PER SAMPLE & 2.00 & Liters & & & & IOTAL VOLUME PER SAMPLE & 0.20 & Liter & - & \\
\hline Tritlum pet SAMPLE & & & & & & Tritium pes sample & & & - & \\
\hline $\mathrm{NH} 3 \mathrm{i}$ (5am) & $\leq$ Defectapie & pci per giam & & & & TST (4.5 gram) & < Detectable & pciper gram & & \\
\hline H2O (5 gam) & Defectable & pCi per gram & _. & & 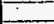 & ALPH $\bar{A}$ per Sample. & & & _ & \\
\hline ALPHA per SAMPLE & & & & & & TST (4.5 gram) & SDelectable & pajper gram & & \\
\hline NH3 $(5 \mathrm{gram})$ & SDetectable & palper gram & & & & BErÁ pér Sample & & & _. & \\
\hline $420(5$ gram $)$ & Detectable & pciper gram & & & & Istr( $4.5 \mathrm{gram})$ & Oelectable & pclper gram & . & \\
\hline BETADer SAMPLE & & & & & & GEA per Sample & Detectable & pciper gram & - & \\
\hline $\mathrm{NH}_{3}(5 \mathrm{gram})$ & $<$ Detectable & Ciper gram & & & & & & & 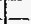 & \\
\hline H2O (5 gram) & CDelectable & DCi per gram & & & & & & & - & \\
\hline GEA per SAMPLE & $\leq$ Detectable & pCi per gram & & & & & & & E & \\
\hline SUMMA SAMPLING & & & & & & & & & - & \\
\hline TOTAL VOLUME PER CANISTER & & Lilers fair at 30 & Dok & $1 \mathrm{bar}=1.161$ & gL) & & & & $\ldots$ & \\
\hline Trithu PER SAMMPLE & $<$ Detectable & pi per gram & & & & & & & $\ldots$ & \\
\hline BETA PER SAMMPLE & $<$ Qetectable & pCi pergram & ह & & & & & & - & \\
\hline ALPHA PER SAMMPLE & SDetectable & pal per gram & & & & & & & - & \\
\hline GEAPER SAMPLE & DDetectable & pGi per gram & & & & & & & & \\
\hline
\end{tabular}


HNF-SD-WM-RPT-233, Rev. 0

This page intentionally left blank.

A- 8 
HNF-SD-HM-RPT-233, Rev. 0

APPENDIX B

AMBIENT CONDITIONS

B-1 
HNF-SD-WM-RPT-233, Rev. 0

This page intentionally left blank. 


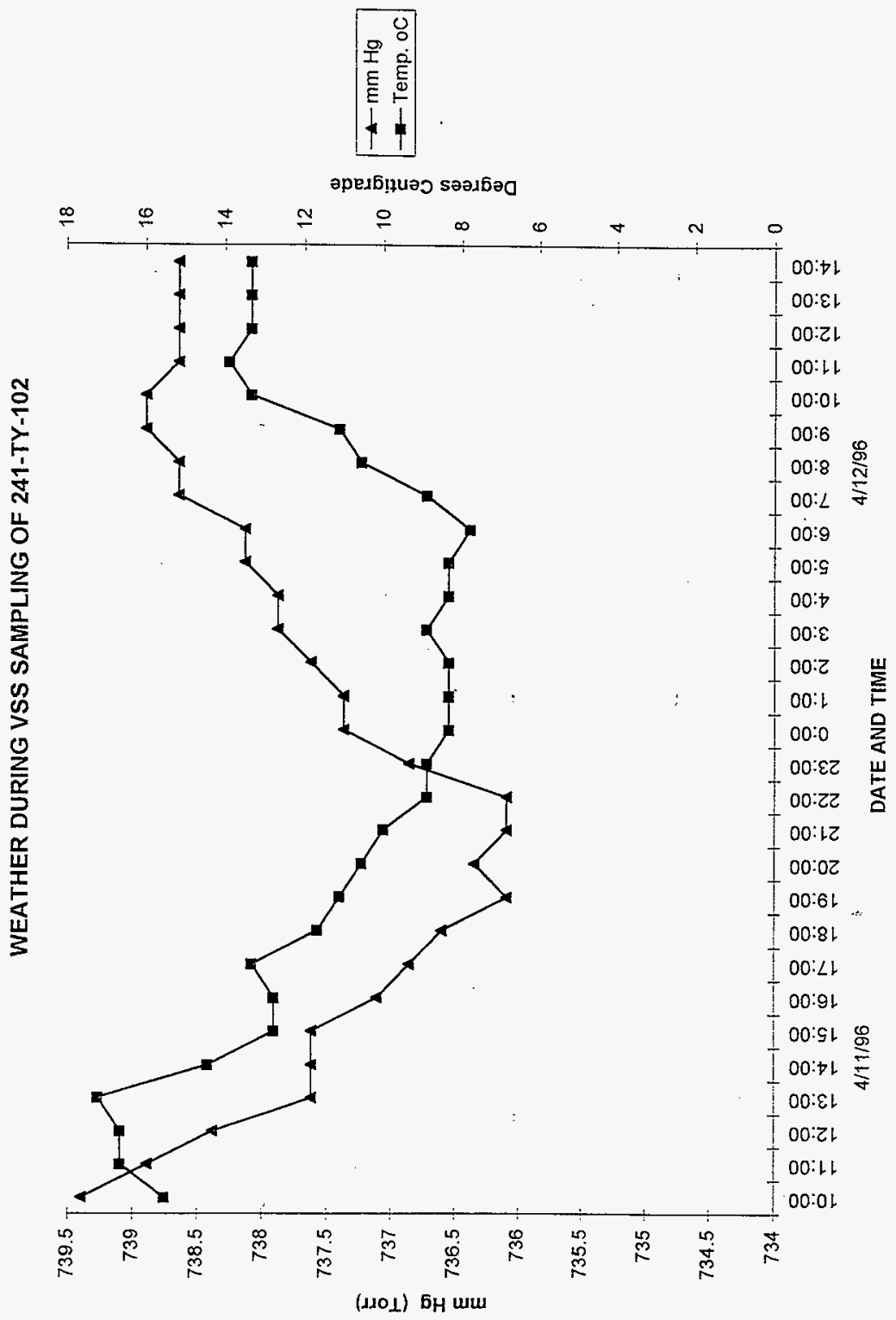


HNF-SD-WM-RPT-233, Rev. 0

This page intentionally left blank.

B -4 
HNF-SD-WM-RPT-233, Rev. 0

APPENDIX C

CHAIN-OF-CUSTODY FORMS

C-1 
HNF-SD-WM-RPT-233, Rev. 0

This page intentionally left blank.

C -2 


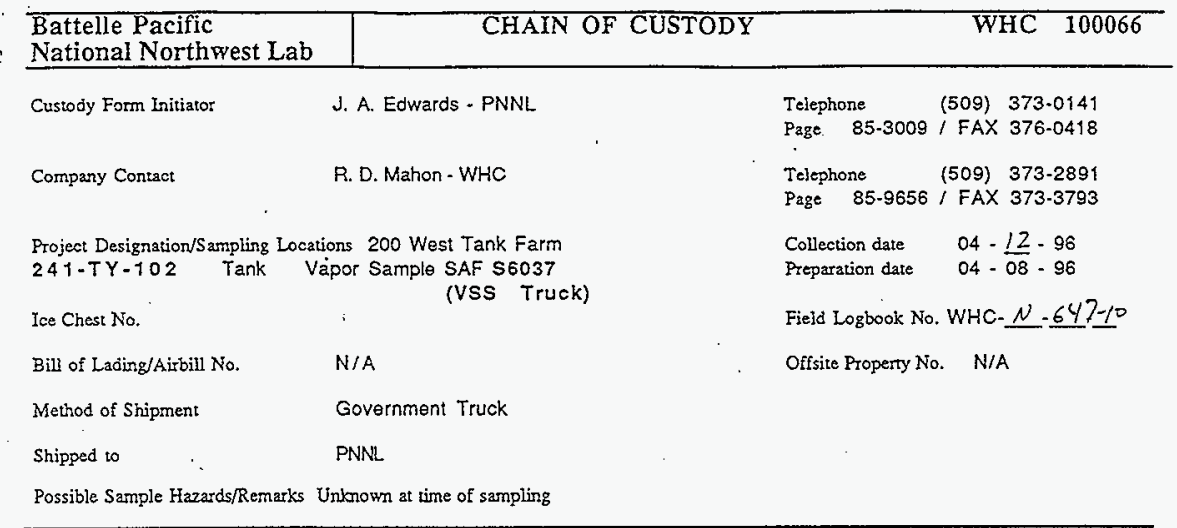

Sample Identification

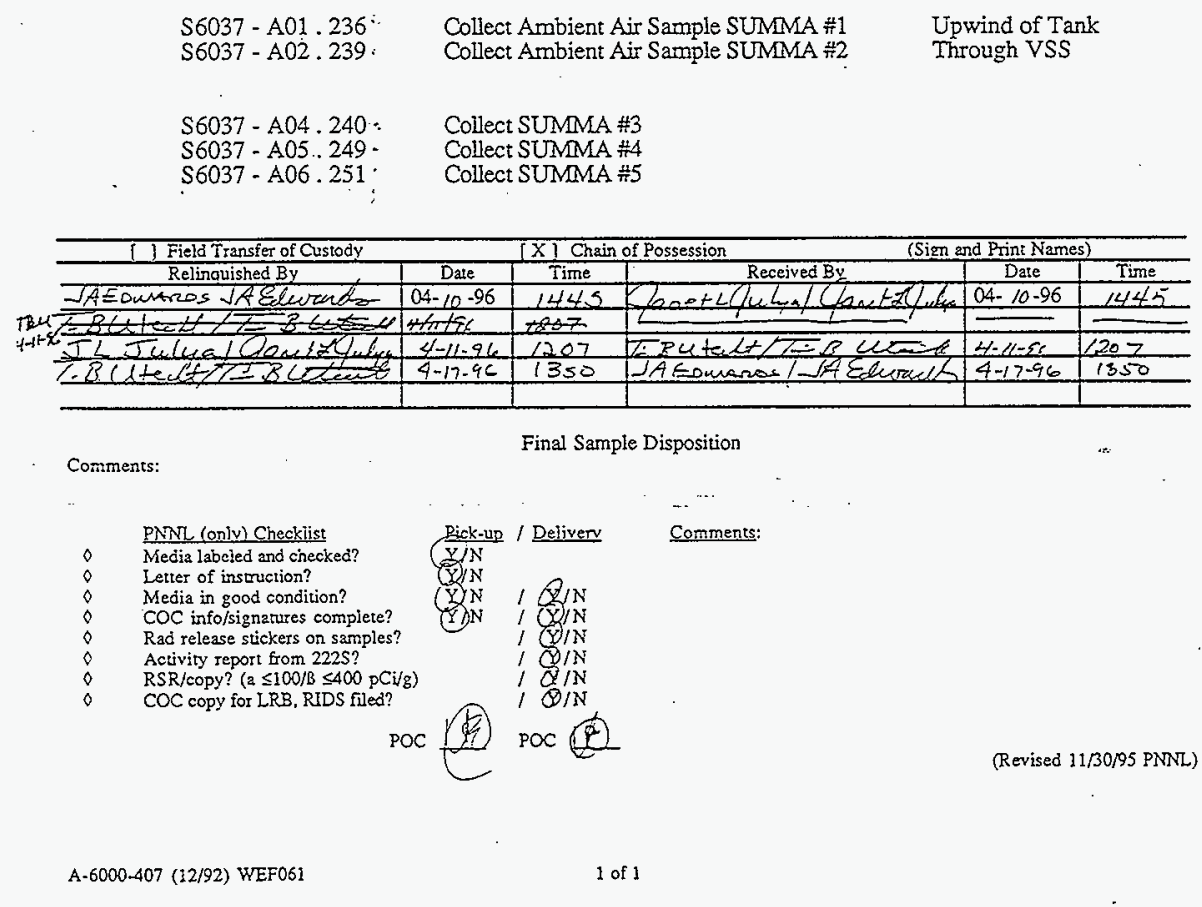


Battelle Pacific National Northwest Lab

CHAIN OF CUSTODY $\quad$ WHC 100068

Custody Form Initiator

J. A. Edwards - PNNL

Telephone (509) 373.0141

Page 85.3009 / FAX 376-0418

Company Contact

R. D. Mahon - WHC

Telephone (509) 373-7437

Page 85-9656/FAX $373-3793$

Project Designation/Sampling Locations 200 West Tank Farm

$241-T Y-102$ Tank Vapor Sample SAF $\mathbf{S 6 0 3 7}$

Collection date $04 \cdot 12 \cdot 96$

Preparation date $04 \cdot \overline{08} \cdot 96$

Ice Chest No.

Field Logbook No. WHC. N. 64710

Bill of Lading/Airbill No.

N/A

Offsite Property No. N/A

Method of Shipment

Government Truck

Shipped to

PNNL

Possible Sample Hazards/Remarks Unkown at time of sampling

Sample Identification

S6037-A07. $\$ 49^{\circ}$
S6037-A08. S50
S6037-A09. S51
S6037-A10. $\$ 52^{\circ}$

$\$ 6037-A 15 . \$ 53$

S6037 - A16.S54:
Collect $\mathrm{NH}_{3} / \mathrm{NO}_{x} / \mathrm{H}_{2} \mathrm{O}$ Sorbent Trap

Collect $\mathrm{NH} 3 / \mathrm{NO}_{2} / \mathrm{H}_{2} \mathrm{O}$ Sorbent Trap

Collect $\mathrm{NF}_{3} / \mathrm{NO}_{\mathrm{X}} / \mathrm{H}_{2} \mathrm{O}$ Sorbent Trap

Collect $\mathrm{NH} / 3 / \mathrm{NO}_{x} / \mathrm{H}_{2} \mathrm{O}$ Sorbent Trap

Open, close and store $\mathrm{NH}_{3} / \mathrm{NO}_{2} / \mathrm{H}_{2} \mathrm{O}$ field blank $\# 1$

Open, close and store $\mathrm{NH}_{3} / \mathrm{NO}_{\mathrm{X}} / \mathrm{H}_{2} \mathrm{O}$ field blank

\begin{tabular}{|c|c|c|c|c|c|}
\hline 1 ] Fjeld Transfer of Custody & & X] Chai & of Possession & Id Print Name & \\
\hline Relinouished By & Date & Time & Received By & Date & Time \\
\hline GWDenis $3 . \omega S)$ & $04-10.96$ & 1345 & 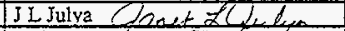 & $04-10-96$ & 1345 \\
\hline 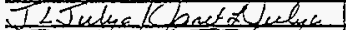 & $04-11-96$ & 1207 & 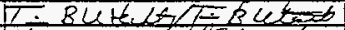 & $04-11-96$ & 1207 \\
\hline 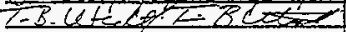 & $4-17-96$ & 1350 & 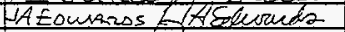 & $4-17-96$ & 1350 \\
\hline & & & 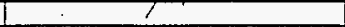 & & \\
\hline & & & & & \\
\hline & . & & & & $\therefore$ \\
\hline
\end{tabular}

Comments:

Final Sample Disposition

PNNL (oniv) Checklist

Media labeled and checked?

Letter of instruction?

Media in good condition?

$\mathrm{COC}$ info/signatures complete?

Rad release stickers on samples?

Activity report from $222 S$ ?

RSR/copy? (a $\leq 100 / 3 \leq 400 \mathrm{pCi} / \mathrm{g}$ )

COC copy for LRB, RIDS fled?
Commenis:

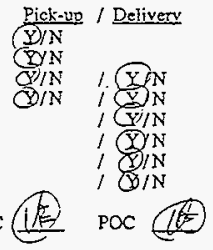

1 of 1 


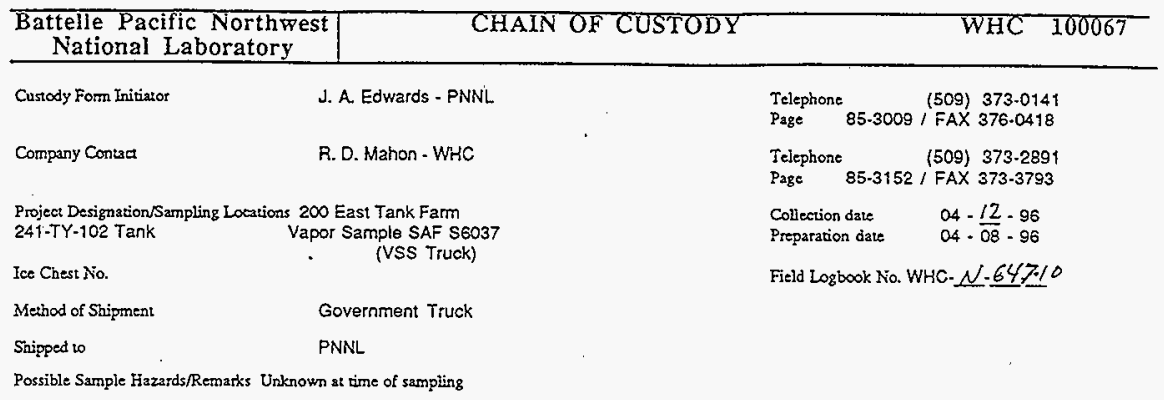

Sample Identification

$\begin{array}{ll}\text { S6037 - A11.92\%, } & \text { TST(Triple Sorbant Tube) Sample \#1 } \\ \text { S6037-A12:922: } & \text { TST Sample \#2 } \\ \text { S6037 - A13 } .923^{\circ} & \text { TST Sample \#3 } \\ \text { S6037 - A14.925. } & \text { TST Sample \#4 }\end{array}$

$\begin{array}{lll}\text { S6037 - A17 } 926 . & \text { TST Field Blank } \# 1 & \text { Open in VSS Truck } \\ \text { S6037 - A18. } 927 . & \text { TST Field Blank } \# 2 & \text { Open in VSS Truck }\end{array}$

S6037 - A19 . 928. TST Trip Blank \#1

S6037 - A20 . 929, TST Trip Blank

\begin{tabular}{|c|c|c|c|c|c|}
\hline (1) Fieid Transfer of Custody & & X] Chai & of Possession & nd Print Names & \\
\hline Relinguished By & Date & Time & Receiyed By & Date & Time \\
\hline J.L. Julya Cloose 2 Culua & 04.10 .96 & 0430 & JA Edwards -1 t Elurene's & $04-10-96$ & 0930 \\
\hline VAEDurans SAEqurales & $04-10-96$ & 1345 & 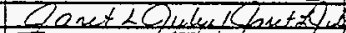 & $04-\angle 0-96$ & 1345 \\
\hline 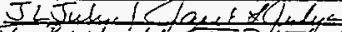 & $4-11-90$ & 1207 & 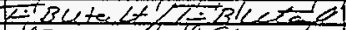 & $4-11-96$ & 1207 \\
\hline 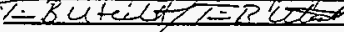 & $-4-17-96$ & 1350 & 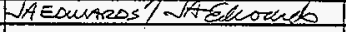 & $4-17-96$ & 1350 \\
\hline & & & & & \\
\hline & & & & & \\
\hline & & & & & \\
\hline Comments: & & & le Disposition & & \\
\hline PNL (onlv) Checklist & Pick-up & / Delivery & Comments: & & $\Leftrightarrow$ \\
\hline Mecia labeled and checked? & $Y N$ & & & & \\
\hline Media in good condition? & & & & & \\
\hline $\begin{array}{l}\text { COC info/signatures complete? } \\
\text { Sorbents shipped on ice? }\left(<5^{\circ} \mathrm{C}\right)\end{array}$ & $\begin{array}{l}Y / N \\
Y / N\end{array}$ & $\begin{array}{l}/ O D N \\
/ \mathrm{B} / \mathrm{N}\end{array}$ & Cooler Temperante Sta & $\div 6$ & \\
\hline $\mathrm{Hi} / \mathrm{L} \mathrm{o}$ thermometer - Keep worighll & Y N & & ${ }^{\circ} \mathrm{C} / \mathrm{Lo} \ldots{ }^{\circ} \mathrm{C}$ (pick up at PN & NNL to WHC) & 1 \\
\hline $\mathrm{Hi} / \mathrm{L}$ thernometer & & 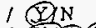 & $\mathrm{Hi}{ }^{\circ} \mathrm{C} / \mathrm{Lo}{ }^{\circ} \mathrm{C}$ (delivery at $\mathrm{V}$ & VHC from $\mathrm{PNN}$ & )) \\
\hline Rad release stickers on samples? & & & C $/ \mathrm{Hii}={ }^{\circ} \mathrm{C} / \mathrm{Lo}-{ }^{\circ} \mathrm{C}$ (at retsm to $\mathrm{P}$ & NNL from WH & c) 1 \\
\hline $\begin{array}{ll}0 & \text { Activity report from } 2225 ? \\
0 & \text { COC copy for LRB, RTDS filed? }\end{array}$ & 77 & 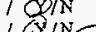 & $1 / 10 \mathrm{LH}+\mathrm{i}+60^{\circ} \mathrm{C} / 10-24^{\circ} \mathrm{C}$ (at deliverv $\mathrm{f}$ & Iom WHC to $\mathrm{P}$ & \\
\hline & & & & Revised 0 & 6 PNNL) \\
\hline
\end{tabular}




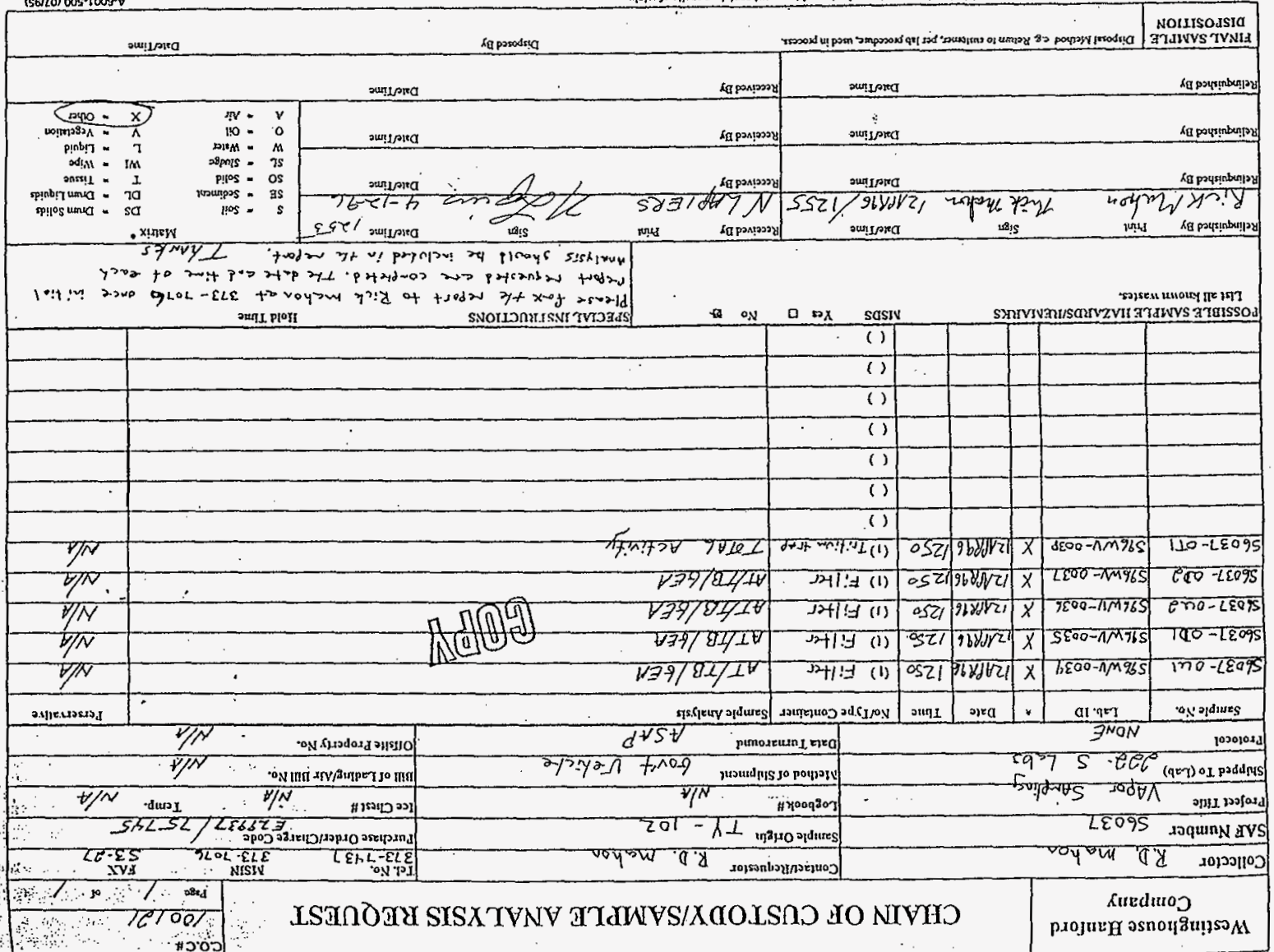




\section{DISTRIBUTION SHEET}

\begin{tabular}{|c|c|c|c|c|c|}
\hline \multirow{2}{*}{$\begin{array}{l}\text { To } \\
\text { Distribution }\end{array}$} & \multirow{2}{*}{\multicolumn{3}{|c|}{$\begin{array}{l}\text { From } \\
\text { Speciai Analytical Support, } \\
\text { Numatec Hanford }\end{array}$}} & \multicolumn{2}{|l|}{ Page 1 of 1} \\
\hline & & & & \multicolumn{2}{|l|}{ Date $8 / 7 / 97$} \\
\hline \multicolumn{4}{|l|}{ Project Title/Work Order } & \multicolumn{2}{|c|}{ EDT No. 614235} \\
\hline VAPOR AND GAS SAMPLING USING T & IN SITU VAPOR & SAMPLING & YSTEM & \multicolumn{2}{|c|}{ ECN No. } \\
\hline Name & MSIN & $\begin{array}{l}\text { Text } \\
\text { With All } \\
\text { Attach. }\end{array}$ & Text Onf & $\begin{array}{l}\text { Attach./ } \\
\text { Appendix } \\
\text { Only }\end{array}$ & $\begin{array}{c}\text { EDT/ECN } \\
\text { Only }\end{array}$ \\
\hline
\end{tabular}

Lockheed Martin Hanford Company
L. L. Buckley
R2-12
$x$

Lockheed Martin Services, Inc.

Central Files

A3-88

$x$

SGN Eurisys Services Corporation

E. S. Mast

\$3-90

$x$

PNNL

J. L. Huckaby

$K 6-80$

$x$ 